Matgorzata SZLAMIŃSKA

Fish feeding

\title{
INTESTINE EVACUATION RATE IN CYPRINID LARVAE FED ON TWO KINDS OF DRY FEEDS AT $24^{\circ} \mathrm{C}$
}

\author{
TEMPO OPRÓŻNIANIA JELITA PRZEZ LARWY RYB \\ KARPIOWATYCH ŻYWIONE PASZAMI SZTUCZNYMI W TEMPERATURZE $24^{\circ} \mathrm{C}$
}

\author{
Department of Ecological Bioenergetics \\ Institute of Ecology \\ Polish Academy of Sciences \\ Dziekanów Leśny
}

\section{SHORT COMMUNICATION}

Investigations of the evacuation rate of fish larvae may have both theoretical and practical bearing. In the first case they may serve, among others, as data for the determination of the passage time of the food through the intestine and consequently, help to settle the daily food ration of fish. In fishing practice those data may be exploited as auxiliary in the determination of biotechnics of larvae feeding, particularly of the feeding frequency.

The experiment was performed at a temperature of $24^{\circ} \mathrm{C}$. Three groups of cyprinid fish larvae were used: four-day-old common carp (Cyprinus carpio L). designed later group $\mathbb{K} 4$, for which the carp start food, Ewos larvstart C-10 was their first food; ten-day-old common carp (group $\mathbb{K} 10$ ), which had been previously fed with this same food for seven days; ten-day-old grass carp (Cienopharyngodon idella Val. - group A10), which had been given commercial trout start food produced in Poland, for 7 days. The characteristics of onvestigated fish have been presented in tab. 1 and 2 .

Food C-10 may be recognized as satisfactory in the rearing of carp larvae (Szlamińska 1980), instead repeated test (Okoniewska et al. 1986, Szlamińska - unpublished data) have shown that trout food used as first food gives no growth of cyprinid fish. 
Characteristics of investigated fish - basic data

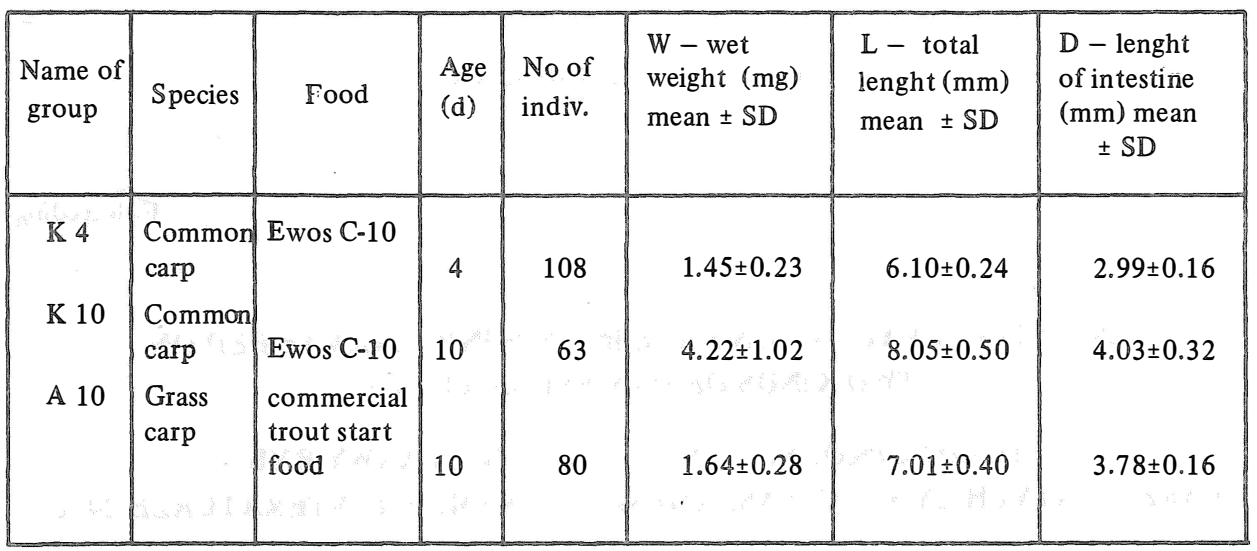

Table 2

Characteristics of investigated fish. Relationship between: lenght of fish $(\mathbb{L}, \mathrm{mm})$ and lenght of intestine $(D, m m)$, linear fit: $\mathbb{L}=a+b D$, wet weight of fish (W, $m g)$ and lenght of intestine $(D, m m)$, power curve fit: $\mathrm{W}=\mathrm{aDb}$, wet weight of fish $(W, m g)$ and lenght of fish $(L, m m)$, power curve fit: $W=a L^{b}$.

\begin{tabular}{|c|c|c|c|c|c|}
\hline $\begin{array}{c}\text { Name of } \\
\text { group }\end{array}$ & $\begin{array}{c}\text { No of. } \\
\text { indiv. }\end{array}$ & $\begin{array}{c}\text { Correl. } \\
\text { coeff. }\end{array}$ & Regression line & $\begin{array}{c}95 \% \text { confidence } \\
\text { limits for a }\end{array}$ & $\begin{array}{l}95 \% \text { confi- } \\
\text { dence in- } \\
\text { tervals } \\
\text { for b }\end{array}$ \\
\hline K 4 & 108 & 0.71 & $\mathbb{L}=2.807+1.102 \mathrm{D}$ & $2.184-3.430$ & 0.208 \\
K 4 & 108 & 0.40 & $\mathrm{~W}=0.388 \mathrm{D}^{1.193}$ & $0.367-0.411$ & 0.533 \\
K 4 & 108 & 0.38 & $\mathrm{~W}=0.097 \mathrm{~L}^{1.488}$ & $0.055-0.172$ & 0.705 \\
\hline K 10 & 63 & 0.80 & $\mathbb{L}=3.085+1.231 \mathrm{D}$ & $2.117-4.053$ & 0.239 \\
K 10 & 63 & 0.69 & $\mathbb{W}=0.179 \mathrm{D}^{2.249}$ & $0.141-0.227$ & 0.598 \\
K 10 & 63 & 0.78 & $\mathrm{~W}=0.006 \mathrm{~L}^{3.160}$ & $0.003-0.012$ & 0.654 \\
\hline A 10 & 80 & 0.76 & $\mathbb{L}=0.964+1.600 \mathrm{D}$ & $-0.210-2.138$ & 0.310 \\
A 10 & 80 & 0.73 & $\mathrm{~W}=0.045 \mathrm{D}^{2.693}$ & $0.037-0.054$ & 0.564 \\
A 10 & 80 & 0.78 & $\mathrm{~W}=0.016 \mathrm{~L}^{2.364}$ & $0.011-0.025$ & 0.432 \\
\hline
\end{tabular}

${ }^{1}$ All correlation coefficients were significant at $1 \%$ level. 
After a whole nights starvation the fish were fed intensively for 2 hours, then transferred to another container where they weren't fed any more. Every hour (group $\mathbb{K} 4$ ) or every 2 hours (groups $\mathbb{K} 10$ and $A 10$ ) samples of larvae were collected, 8 to 15 specimens each. Fish were fixed in a $4 \%$ formaldehyde solution and investigated under a microscope with screen "Projectina" (magnification 10 and 20x). The lenght of gut sections containing chyme as well as the total lenght of intestine and the lenght of fish (Longitudo chordalis) were measured. The base of pectoral fins was assumed as the initial point of the intestine and the anus - as its end. The fish were weighed to an accuracy $0,1 \mathrm{mg}$. The ratio of the sum of filled sections lenght to the whole intestine lenght expressed as percentage, was assumed as measure of the gut filling.

There were no substantial differences in the average feeding intensity of larvae in all experimental groups, i.e. there were no statistically significant differences in the filling degree of the intestine at the moment of feeding cessation (hour 0, Fig. 1.). Four-day-old common carps (group $\mathbb{K} 4$ ) evacuated their gut very soon after cessation of feeding. As soon as after 1 hour over $50 \%$ of the intestine length was empty. However, during the next 6 hours of observation the filling level of the gut was more or less unchanged (Fig. 1).

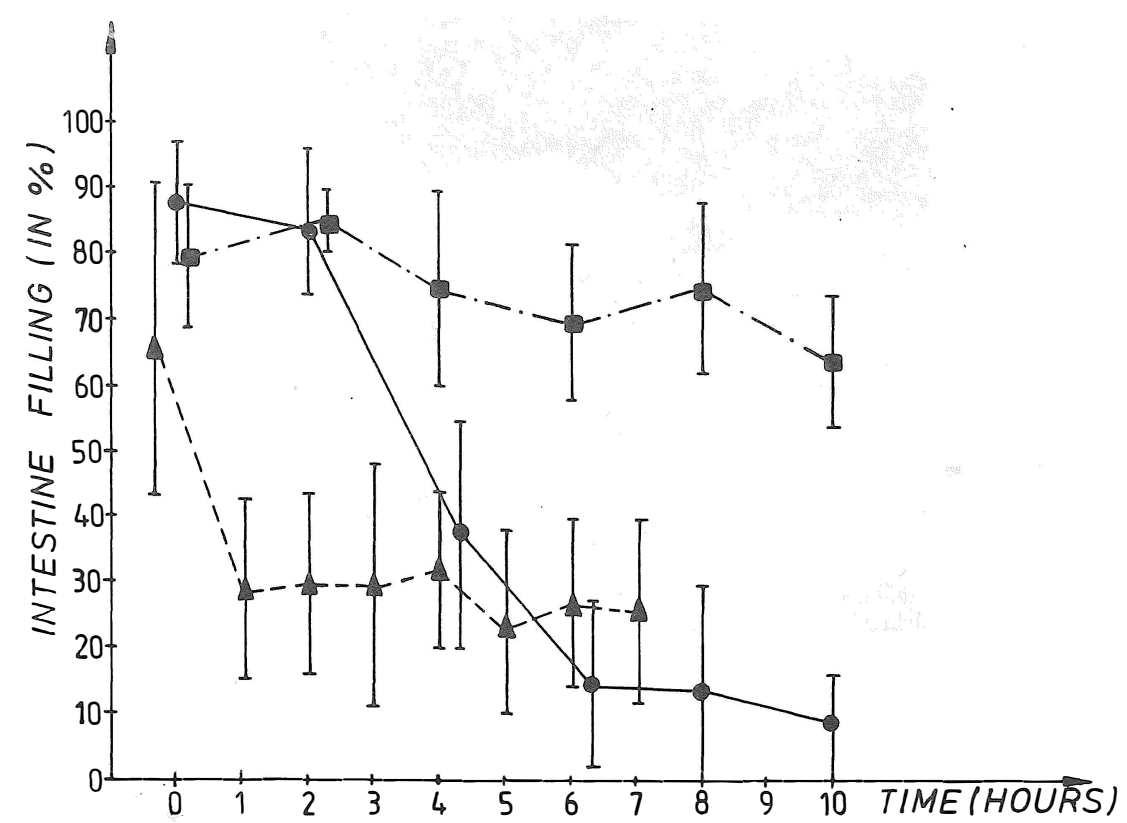

Fig. 1. Mean gut filling of fish larvae during evacuation. Vertical lines: $95 \%$ confidence limits for the mean

$$
\begin{aligned}
& --\Delta---4-\text { day- old common carp (K4) } \\
& -\bullet-10-\text { day- old common carp (K10) } \\
& -\cdot-\cdot 10-\text { day- old grass carp (A 10) }
\end{aligned}
$$



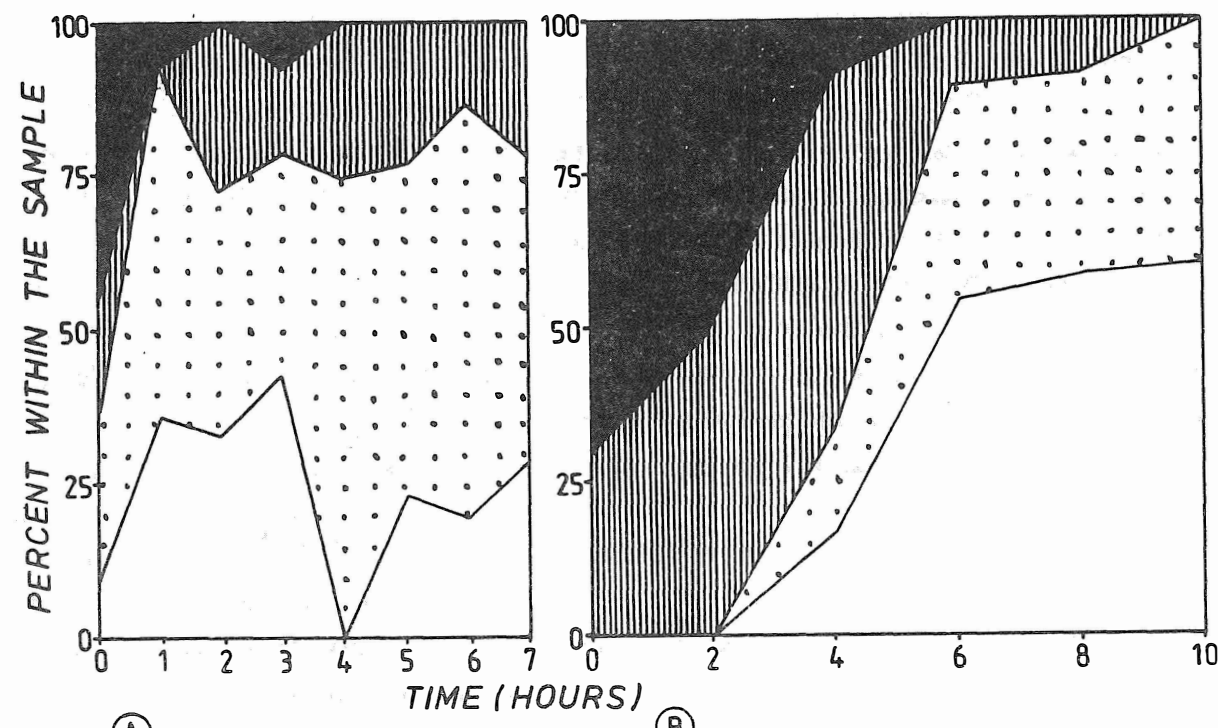

(A)

(B)

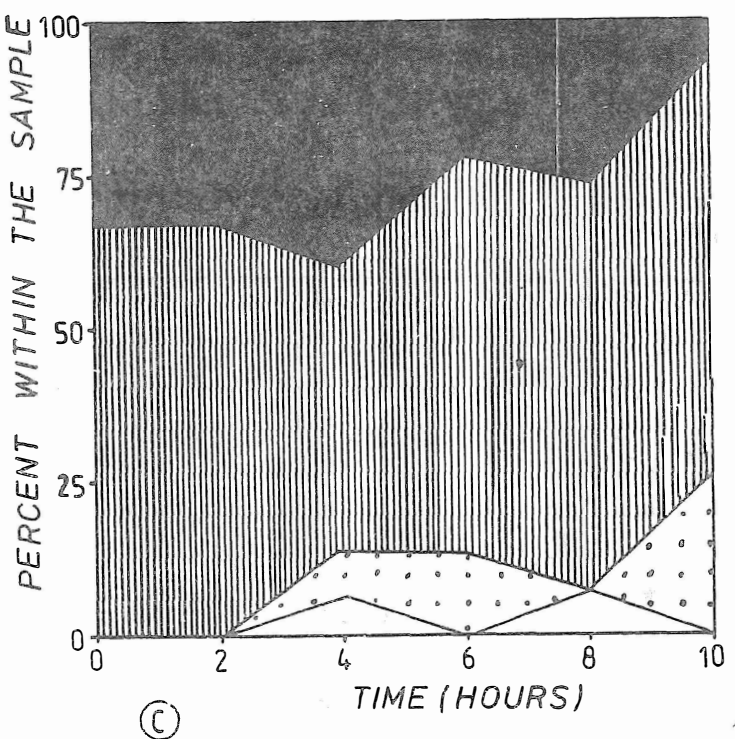

Fig. 2. Structure of guts filling in sa mples collected.

gut filled to $90-100 \%$

[III] guts filled to $50-89,9 \%$

$\because:$ guts filled to $10,1-49,9 \%$

$\square$ guts filled to $0-10 \%$ 
In group $\mathrm{K} 10$ the evacuation process had a different course (Fig. 1). The food filled the intestine for 2 hours. Only between the third and the fifth hour $50 \%$ of the gut lenght was emptied. From the 6 hour on the evacuation rate became much lower.

The grass carp (A10) intestine was filled to over 50\% still after 10 hours. There was no violent decrease of gut filling which occured in the other groups (Fig. 1).

The intestine filling structure observed in successive samples is presented in Fig. 2. Four types of intestine filling have been distinguished: full i.e. filled to $90-100 \%$, well filled $(50-89,9 \%)$, poorly filled $(10,1-50 \%)$, and unfilled i.e. empty or filled to $10 \%$.

Younger common carp (K4, Fig. 2a) showed drastic changes in the filling structure during the first hour of evacuation. The percentage on unfilled intestine grew between the 1 st and 2 nd hour while the part of well filled and full gut decrease violently. From the 3rd hour on the part of unfilled gut showed a declining tendency while the percentage of poorly filled gut increased slightly. A more or less unchanged level of well filled gut was observed during that time. After 4 hours there were no full intestine (Fig. 2a).

In the group of older common carp, K10 (Fig. 2b) there was an even decrease of the full gut part, till its disappearance by the 6 th hour. The percentage of well filled intestine decreased gradually while the amount of poorly- filled and unfilled gut increase. Between the 6 th and the 10 th hour the filling structure displayed a tendency to stabilization. The percentage of well- filled intestine decreased at a much slower pace and the percentage of poorly- filled and unfilled gut slightly increased (Fig. 2b).

In the grass carp group, A10, (Fig. 2c), the percentage of full intestine tended to decrease slightly during evacuation. From the 4 th hour on the occurence of a small percentage of unfilled and poorly filled gut was noticed. Well- filled gut prevailed in the samples (Fig. 2c).

It may be stated on the basis of the gathered data that the evacuation time of carp larvae taking food for the first time differs from the time of those fed during 7 days. Younger fish (K4) evacuate their gut during 1 hour after feeding and thus they are sooner able to take another portion of food than older fish $(\mathrm{K} 10)$ which keep the food in their intestine for some time after feeding. The prolonged stay of the food in the gut must be connected with digestion and assimilation process. It is also possible that the fish need some impulse, a "pusher", i.e. that the new food portion should push the chyme out of intestine. There may be a connection with the tendency of fish larvae to overfilling the gut, so that the work of their muscles cannot shift the chyme rapidly. With the method used it was impossible to state the facts described above.

In the grass carp group (A10) trout food stayed in the gut for a very long time. It may be supposed that the small changes in the mean (Fig. 1) and of the structure (Fig. 2c) of intestine filling resulted in most cases from a strictly mechanical decrease of the chyme volume (pressure, ect.). However, it can not be excluded that the food is excreted in small portions or that some part of population is able to evacuate their guts of that food, partir ularly if a small portion has been taken.

Relatively few investigations have been carried out so far of the evacuation rate and the passage time of food through the fish larvae intestine. Laurence (1971) quotes 
K. Chiby's paper (1961) where the author stated that in the temperature range of $18-29^{\circ} \mathrm{C}$ the evacuation time of carp larvae was 1 to 8 hours. He bably fed the larvae in a continuous way and only differentiated the food so as to observe the moment when the fish removed a marked portion. If we used continuous feeding in the present experiment the passage of the food through the intestine would be faster than the evacuation. Laurence (1971) stated that the time of food passage through the intestine of Microptenus salmonides larvae fed continuously was twice as short as that of larvae fed once.

\section{CONCLUSIONS}

1. The gut evacuation time of four-day-old common carp larvae, taking their first food (Ewos C-10) is relatively short. It may be assumed that after 1 hour the larvae is emptied in $50 \%$.

2. The gut evacuation time of ten-day-old larvae of common carp, fed on this same food during the previous 7 days is slightly longer than that of four-day-old fish. The evacuation of $50 \%$ of gut lenght occurs between the $3 \mathrm{rd}$ and 5 th hour of evacuation. During the first 2 hours the food stays in the intestine.

3. Trout food stays during 10 hours after feeding in the gut of tenday-old grass carp larvae, previously fed on this food for 7 days.

4. It may be inferred from the analysis of the gut evacuation time of cyprinid fish larvae that the terason of poor growth of grass carp larvae fed on trout food is the stoppage of guts with the food. This does not occur in common carp larvae fed on dry food Ewos $\mathrm{C}-10$, and it is probable one of the factors conditioning some growth reached by this fish.

5. During the ontogenesis of the carp there occur changes in the gut evacuation time which should be taken into consideration while planning the feeding frequency in larval rearing conducted on a production scale. Younger fish need more frequent feeding, we suggest a minimum frequency of every $15 \mathrm{~min}$., while older fish can get food less frequently: every 1 or 2 hours.

\section{ACKNOWLEDGEMENTS}

The author thanks heartily assis. prof. Ewa Kamler for her precious remarks concerning the present paper. 


\section{REFERENCES}

Laurence G.C., 1971: Digestion rate of larval largemouth bass. NY Fish and Game J., 18 1:52-56.

Okoniewska G., Opuszczyńska W., Opuszczyńska K., Wolnicki J., Myszkowski L., 1986: Podchów wylęgu ryb karpiowatych $w$ basenach przy użyciu pokarmu naturalnego i paszy. Materiały XIII Zjazdu Hydrobiologów Polskich, 16-19.09.1986: 148-149. [Breeding of the Cyprinidae fish hatch in basins by means of a natural food and feed]. Materials of the 13-th Session of Polish Hydrobkologists. Szczecin, 16-19.09.1986: 148-149.

Szlamińska M., 1980: Wstępne wyniki żywienia larw karpia starterem C-10 firmy Ewos. Gosp. Ryb. (1980), 7:8-9. [Preliminary results of the carp larvas feeding with starter C-10 feed, produced by ,Ewos“]. Gosp. Ryb. (1980), 7:8-9.

Translated: Dr M. Szlamińska

Małgorzata Szlamińska

\section{TEMPO OPRÓŻNIANIA JELITA PRZEZ LARWY RYB KARPIOWATYCH ŻYWIONYCH PASZAMI SZTUCZNYMI W TEMPERATURZE $24^{\circ} \mathrm{C}$}

\section{STRESZCZENIE}

Badania przeprowadzono na 2 gatunkach ryb karpiowatych: karpiu (C.carpio L.) w wieku 4 i 10 dni oraz amurze białym (C.idella) w wieku 10 dni. Karpiom podawano przeznaczony specjalnie dla ryb karpiowatych granulat „Ewos” larvstart C-10, zaś amurowi granulat pstragowy. Karp w wieku 4 dni podczas 1 godziny po zaprzestaniu podawania pokarmu opróżniał ponad 50\% długości jelita. U larw starszych (10 dni) proces ten przebiegał wolniej : jelito było opróżniane w $50 \%$ między 3 a 5 godziną. Przez pierwsze 2 godziny opróżniania pasza zalegała w jelicie. W przypadku amura białego stwierdzono zaleganie pokarmu w jelicie podczas 10 godz. po zaprzestaniu żywienia. Świadczy to o braku tranzytu jelitowego, w czym upatrywano przyczynę znikomych przyrostów ryb karpiowatych żywionych paszą przeznaczoną dla łososiowatych.

Author's address:

Dr Małgorzata Szlamińska

Instytut Ekologii

Polska Akademia Nauk

Dziekanów Leśny

05-150 Łomianki

POLSKA (Poland) 